\title{
Human birth and spiritual rebirth in the theological thought of John Chrysostom
}

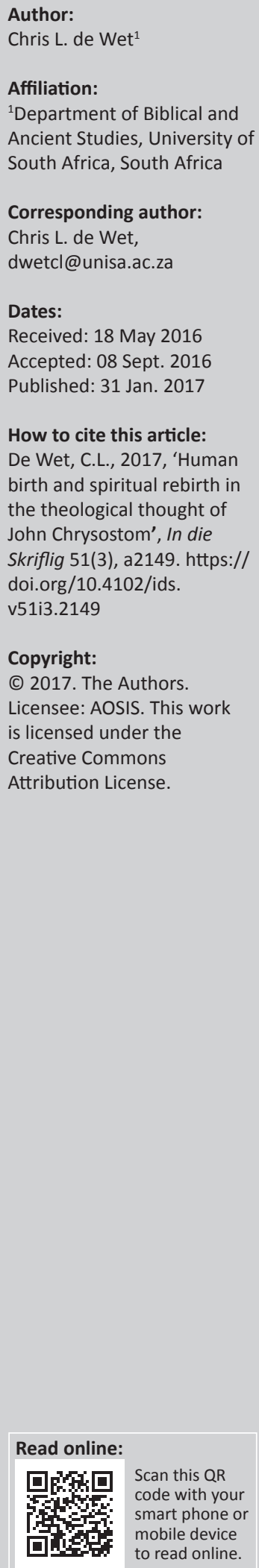

The purpose of this article is to investigate the dynamics between human birth and spiritual rebirth in the thought of John Chrysostom (349-407 CE) and to position these dynamics in the broader scope that is salvation history.

Utilising the aspects of the methodology of Van der Watt on the dynamics of metaphor in the New Testament, the article contextualised Chrysostom's understanding of spiritual rebirth within the progressive and climactic unfolding of human reproduction between prelapsarian and postlapsarian states.

In the first instance, the reproductive shift from divine creation to human reproduction after the Fall of Adam and Eve was discussed. Thereafter followed a discussion of how the miraculous births of men by barren women in the Old Testament such as Sarah and Isaac, functioned as a typological device pointing towards spiritual rebirth. After this an analysis of Chrysostom's understanding of the virgin birth of Jesus by Mary was given, showing again that this birth event was yet another typological device that directed the faith of the believer towards spiritual rebirth. Finally, Chrysostom's teaching on the nature of spiritual rebirth is discussed in light of this broader typological development.

The result was that the notion of spiritual rebirth in Chrysostom's thought could not be understood separately from his views on human birth and the progression back to a prelapsarian state of generation.

The relevance of the article is that it presents a focused study both on Chrysostom's theology and his soteriology, in particular as well as his social thought with regards to sexual morality and issues related to reproduction and birth.

\section{Introduction}

It is more than fitting to examine the afterlife of a Johannine metaphor, namely being 'born of

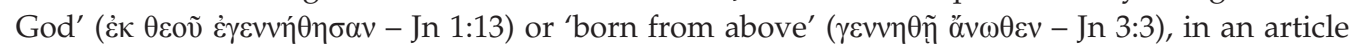
such as this one that is dedicated to and engages with the work of Jan van der Watt. Van der Watt's analyses (2005a:101-132; 2006:107-134; 2013:73-92) of the Johannine literature of the New Testament has been undertaken from numerous perspectives: he has investigated, inter alia, the nature of Johannine salvation, identity and ethics. However, it is Van der Watt's work on the nature of image and metaphor in the Gospel according to John that, perhaps, stands out most of all. The crown of this research is an impressive 467-page monograph, Family of the king: Dynamics of metaphor in the Gospel according to John (Van der Watt 2000), which examines the metaphors of family in John's Gospel. In this book, Van der Watt (2000:166-200) not only investigates the numerous instances of familial imagery in John, including the image of birthing, but he also develops his own theory of metaphor useful in the interpretation of biblical literature. In this theory, the metaphorical devices of substitution, interaction, comparison, climactic description and aesthetics receive priority.

In this article the dynamics between human birth and spiritual rebirth in the theological thought of the 4th-century church father, John Chrysostom (349-407AD), will be examined - relying much on Van der Watt's theory and analysis of Johannine metaphors and soteriology. The aim of the article is to contextualise physical birth and spiritual rebirth within Chrysostom's broader theological and ethical framework, especially as related to salvation history. Chrysostom does not read physical birth and spiritual rebirth in a vacuum, but rather positions these types of birth within a much broader typologically progressive framework, which was also highly pedagogical (Rylaarsdam 2014:91, footnote 239). The initial observations of Van der Watt (2000:173-176) on the metaphor of birth in John, particularly the dynamics of the verb $\gamma \varepsilon v v \alpha$ ó (2000:173-174), seem to 
be relevant also in Chrysostom's reading and application of the image - the image birth is, at least, both interactive and climactic in Chrysostom's thought (see also Van der Watt 2000:114-118).

The interactive nature of the image of birth in Chrysostom is seen in that it occupies a position within an order of other very specific forms of generation, which are first, the generation of Adam from the dust of the earth (which is related to the generation of the angels); second, the generation of Eve from Adam's rib; third, the physical birth of Adam and Eve's children as a result of sexual reproduction; fourth, the miraculous births from the sterile women of the Old Testament, especially Sarah; and fifth, the virgin-birth of Christ from Mary. These preceding forms of generation foreshadow spiritual rebirth, but spiritual rebirth also represents the climax of God's generative and saving power, hence the climactic nature of the metaphor in Chrysostom's thought. Without an understanding of how physical birth and spiritual rebirth operate in this typological framework, one would never fully grasp the fundamentals of Chrysostom's soteriology. But, then, there is also a substitutive and comparative dynamic between physical and spiritual birth: spiritual rebirth is seen as being closer to an original, ideal form of generation, which was in effect before the Fall of Adam and Eve. In the rest of this article, these different typologically progressive phases of birth and rebirth in Chrysostom's soteriology will be examined more closely.

\section{From ideal to deviation: The generation of Adam and Eve}

In order to understand Chrysostom's view on spiritual rebirth, we need to start with the creation narrative in Genesis 1-2. Unlike many modern interpreters, Chrysostom does not read Genesis 1-2 as two separate creation narratives. He views them as a unit and uses one to interpret the other as was common in Patristic readings of the text (De Beer 2015:3-23; Blowers 2012:139-187). In Chrysostom's interpretation of the Genesis 1-2 narrative (as seen especially in Serm. Gn. 1-2; Brottier 1998:138-197), ${ }^{1}$ we may note that he acknowledges an important shift in human reproductivity. There comes a point where creation shifts from fabrication to reproduction - the instance in which the human body, and no longer the earth or the waters, serves as the primary trajectory for creation. It is also the point where creation does not occur simply through the spoken word of God, but via the penetration of the body.

The shift in creation from fabrication to human reproduction is both intensified after the Fall into sin and it also experiences a type of deviation. God has created Adam out of the dust of the earth, but Eve is created out of the

\footnotetext{
1.Note on references to ancient texts: When referring to Chrysostom's works or to that of any ancient author, the first reference will be the location in the original ancient source, the second reference will be the location of the reference in the most recent critical edition of the ancient text, and the third reference will be the source for the translation of the text. In cases where only the first primary and second critical edition references are present, in other words where there is no third reference to a translation, the translation is my own.
}

body - the rib - of Adam. This moment is noted with important details in Chrysostom's 15th homily on Genesis (Hom. Gn. 15; Migne PG 53.118.21-125.51). This is the initial shift from the body of the earth to the body of Adam as origin of creation. However, the intensification and deviation occurs after the Fall when all people will now be born of the body the intensification - but no longer from the body of Adam, the male body, but through the female body of Eve - the deviation. The modus operandi of God's creation before the Fall, whether from the body of the earth or Adam, is considered ideal, while postlapsarian reproduction through the female body is seen as an abhorrent deviation from God's original norm, because it implies sexual intercourse, passion and the pain of labour. The use of the prepositions is important as will be seen shortly. This reproductive shift is very important to mark, because Chrysostom will show that spiritual rebirth represents a shift back to the prelapsarian state.

Now, Chrysostom reads Genesis 1-2 in the context of 1 Corinthians 11:12, the Pauline intertext, which reads: 'For as woman was made from man, so man is now born of woman. And all things are from God' (English Standard Version). Chrysostom's interpretation of this text is very interesting. He states:

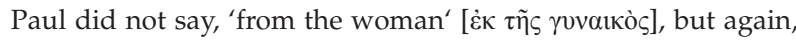

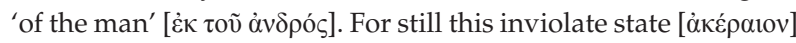
remains with the man. These are not the merits of the man, but of

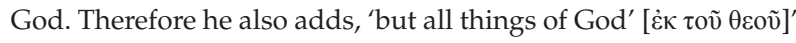
(Hom. 1 Cor. 26.5; Field 1849-1862, 2.317-318).

Two aspects require attention in this regard. First, Chrysostom gives meticulous attention to Paul's use of prepositions in the verse. The correct and accurate reading of prepositional phrases was an important skill in the formation of early Christian doctrine. McDonough (2009:99-101, 147-151) even refers to this as prepositional theology. Chrysostom makes it clear that the woman was made 'from' or 'out of man', highlighting the preposition $\dot{\varepsilon} \kappa$, but, according to 1 Corinthians 11:12, man is made 'through the woman' ( $\delta$ ì̀ $\tau \tilde{\eta} \varsigma$

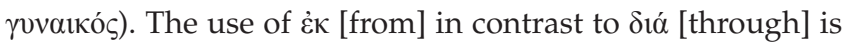
indicative of the postlapsarian reproductive deviation.

The type of generation that was active before the Fall is therefore superior, but it also places the male body as an ideal over and above the female body. Chrysostom states, after all, that prelapsarian generation is an inviolate state

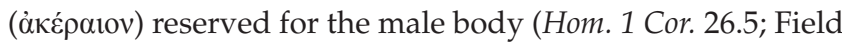
1849-1862, 2.317-318). Chrysostom's use of the term áképatov is significant here. The term àképaros often refers to a state of purity, innocence, simplicity and intactness (related to

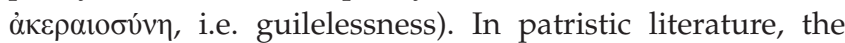
term is used extensively in descriptions of virginity and also the resurrection (Lampe 2010:61). Chrysostom is no exception to this. He primarily sees prelapsarian generation as a virginal mode of reproduction: Eve was created without sexual intercourse. The meaning of àképalos could also be related to the notion of being 'unmixed', referring to undiluted wine or unalloyed metal, but in this case may 
point to a pure state of reproduction that does not imply $\mu$ í $\xi_{1 \zeta}$ [sexual intercourse and the impure commingling ( $\sigma \dot{\gamma} \gamma \chi v \sigma i \varsigma$ ) of seed].

In the generative deviation that is human reproduction, there is now also the need for marriage, sex and lust - this is a major premise in Chrysostom's treatise De virginitate (see Musurillo 1966; Shore 1983). Adam and Eve, according to Chrysostom, were not 'married' as such. Chrysostom asks his audience: 'Why did marriage not appear before the treachery? Why was there no intercourse in paradise? Why not the pains of childbirth before the curse?' He answers: 'Because at that time, these things were superfluous. The necessity arose later because of our weakness, as did cities, crafts, the wearing of clothes, and all our other numerous deeds', (Virg. 15.2.17-22; Musurillo 1966:146-147; Shore 1983:23). Thus, the deviation in the direction of marriage and sexual reproduction resulted in the birth of the city, which was often seen as a place of $\sin$ and filth, in contrast to the rustic country life (see Shepardson 2014:137-142); the generative deviation in human reproduction also caused the development of technology.

Chrysostom then argues that a state of virginity is, ironically, much more fertile than having sexual intercourse: 'Virginity does not cause the human race to dry up but sin and unnatural intercourse do' (Virg. 18.1.3-4; Musurillo 1966:156-157; Shore 1983:27). Chrysostom believes that generation through sexual reproduction is only one inferior and deviated mode of procreation (Virg. 14-19; Musurillo 1966:137-159; Shore 1983:19-29; see also Brown 1988:306-308). Chrysostom proclaims that God could have created more human beings in many other ways without sex such as in the way he created the angels, or from the earth like Adam was created, or from the body of Adam like Eve, that is, in any prelapsarian way. Reproduction through marriage and sexual intercourse is thoroughly postlapsarian. Chrysostom also assures his listeners that procreation by means of sexual intercourse is in any case simply an allowance of God. People can only have children if God is willing - a point that was perhaps quite reasonable considering the high mother and infant mortality rates of ancient times (Shaw 1996:100-138).

At this stage we have noted that there was a shift from an ideal mode of generation and birth to one that is a deviation as the result of the Fall - thus, prelapsarian and postlapsarian generation (or birth). There are three characteristics that separate prelapsarian reproduction from the postlapsarian mode in Chrysostom's thought. First, the prelapsarian mode of generation assumes a perfect, practically angelic, body. This is also why Chrysostom links the creation of Adam and Eve with the creation of the angels (Virg. 14.3.77-79; Musurillo 1966:142-145; Shore 1983:21), and states elsewhere: '[U]p until that time [of the Fall] they were living like angels in paradise ... created incorruptible and immortal, and on that account at any rate they had no need to wear clothes' (Hom. Gn. 15.14; Migne PG 53.123.30-35; Hill 1999a:202-203).
In his exposition of Adam and Eve's bodies, Chrysostom teaches:

Consider, I ask you, the transcendence of their blessed condition, how they were superior to all bodily concerns, how they lived on earth as if they were in heaven, and though in fact possessing a body they did not feel the limitations of their bodies. After all, they had no need of shelter or habitation, clothing or anything of that kind ... [T] his carefree condition of theirs, their trouble-free life and angelic condition. (Hom. Gn. 16.2; Migne PG 53.126.20-28; Hill 1999a:207-208)

Prelapsarian reproduction assumes a perfect angelic body (see also Clark 2015:220-236; for late antique theories of angels and embodiment, see esp. Muehlberger 2013:29-57), which is not troubled by grief, death or pain (Hom. Gn. 17.1; Migne PG 53.134.46-47; Hill 1999a:222). This also helps us to understand the notion of sexual difference and similarity in Chrysostom. Sexual difference was less of an issue before Adam and Eve sinned, because they did not procreate sexually and, according to Chrysostom, could not see each other's nakedness as they were 'clothed in glory'. The only marker of sexual difference, to Chrysostom, was Adam being created in God's image. Eve was apparently not created the same way as Adam in the image of God - an argument also present in 1 Corinthians 11 (Hom. Gn. 8.9; Migne PG 53.72.56-61; Hill 1999a:110). Chrysostom explains:

Blessed Moses, remember, told us that they were naked without feeling shame, for they did not know, after all, that they were naked, clad as they were in ineffable glory, which adorned them better than any clothing. (Hom. Gn. 16.3; Migne PG 53.126.33-37; Hill 1999a:208)

Nudity symbolises a loss of glory, a departure away from angelic corporeality to the weak and sinful human condition. Nakedness is synonymous to human weakness. The postlapsarian body that reproduces sexually, however, is weak and broken - subject to grief, suffering, shame and death. These weaknesses are all wrought on by marriage and sexual intercourse.

The second characteristic of prelapsarian reproduction, which is analogous to the first, is that it assumes a body and a sexuality that remains unstirred by the passions. Chrysostom states that Adam and Eve 'were not burning

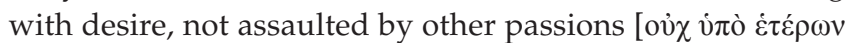

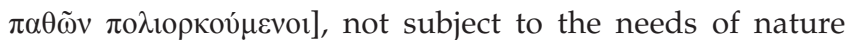

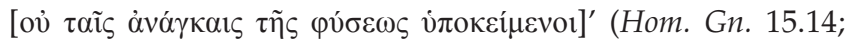
Migne PG 53.123.31-33; Hill 1999a:202-203). The problem of desire $\left(\dot{\varepsilon} \pi 1 \theta v \mu i^{\alpha}\right)$ only arises after the Fall. There is then no need for a passion of attraction between the sexes (Chrysostom's thought here assumes heterosexual attraction; in his commentary on Genesis, here, he is oblivious to the possibility of same-sex passion). After the Fall, Chrysostom is convinced that there was an 'unnaturally' natural desire for a woman installed in every man - one that gives the body pleasure, but also enthralls it (Subintr. 1-2; Dumortier 1955:44-52; Clark 1979:164-170). The prelapsarian mode of reproduction excludes the need for passion, exactly because it is angelic - Chrysostom believes 
that angels are not troubled by the passions (Virg. 10.3.28; Musurillo 1966:124-125; Shore 1983:14). This is an important observation, since Chrysostom further opines that heroes of faith, those exempla of spiritual regeneration, also fully conquered their passions. Of Paul, Chrysostom writes that he 'regarded not only the attractive features of human bodies, but all things, as we do dust and ashes ... So precisely did he lull to sleep the surges of nature, that he never, ever, experienced a single human passion' (Laud. 1.9; Piédagnel 1966:126-127; Mitchell 2002:445). Therefore, although he was still on earth and subject to mortality, Paul was practically angelic (see also Sacr. 4.6; Malingrey 1980:266-267) and already exhibited features of the prelapsarian reproductive body. The same is said of Abraham. The reason why Abraham's rape of Hagar is not seen as adultery is because the passions of lust and jealousy were (conveniently) absent (see Hom. Gn. 38.1-2; Migne PG 53.351-353; Hom. Eph. 20.6; Field 1849-1862, 4.313-314; see also De Wet 2015:234).

This is also why there was a need for marriage. Basing his argument on that of Paul in 1 Corinthians 7, Chrysostom understood that marriage only had one purpose, namely to lull the pangs of lust. The world, according to Chrysostom, was already overpopulated, and therefore marriage was not instituted to encourage procreation-marriage is no longer a necessity for human birth according to the flesh. 'So marriage was granted for the sake of procreation, but an even greater reason was to quench the fiery passion of our nature,' Chrysostom says, referring to 1 Corinthians 7: 'Paul attests to this when he says: "But to avoid immorality, every man should have his own wife" [1 Cor 7:2]. He does not say: for the sake of procreation' (Virg. 19.1.1-5; Musurillo 1966:156-157; Shore 1983:27; see also Subintr. 1.4-20; Dumortier 1955:45; Clark 1979:165-168). Marriage is only useful if it can control lust, but it is not an obligation and is actually only there as a safe haven for those who are weak and cannot control their passions. Following the precepts of Graeco-Roman moral philosophy, Chrysostom affirms that the usefulness of marriage rests in the fact that it has the ability to control

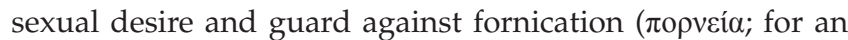
useful overview of the dynamics between marriage and desire in Greek and Roman philosophical thought, see Gaca 2003:264-265; Martin 2006:65-76).

The third characteristic of prelapsarian generation is that it leaves the body unchanged. It is a painless form of generation and the flesh of the body is kept intact. In this regard, Chrysostom says:

'God causes drowsiness to come upon Adam', the text says, 'and he slept' [Gn 2:21]. It wasn't simply drowsiness that came upon him nor normal sleep; instead, the wise and skilful Creator of our nature was able to remove one of Adam's ribs. Lest the experience cause him pain and afterwards he be badly disposed towards the creature formed him from his rib, and through memory of the pain bear a grudge against this being at its formation, God induced in him this kind of sleep: He caused drowsiness to come upon him and bid him be weighed down as though by some heavy weight. His purpose was that, far from allowing man to suffer any sense of what was happening, he should, like some excellent craftsman, do away with mere appearances, supply for any deficiencies and in his own loving kindness create what had thus been taken from man. The text says, remember, 'God caused drowsiness to come upon Adam, and he slept. God took one of Adam's ribs and closed up the flesh in its place' [Gn 2:21] so that after release of sleep he could not feel the loss he was suffering. You see, even if he was unaware at the time of the removal, nevertheless afterwards he would be likely to realize what had happened. So lest he cause him pain in removing it, or the loss of it cause him any distress later, he thus provided for both eventualities by making the removal painless and supplying for the loss without letting him feel anything of what happened. So, the text says, the Lord God took the rib and fashioned it into a woman. A remarkable expression, defying our reasoning with its extraordinary boldness. After all, everything done by the Lord has this character: forming the human being from dust is no less remarkable than this. (Hom. Gn. 15.7; Migne PG 53.120.50-121.12; Hill 1999a:198)

Chrysostom displays his oratorical expertise here and fills in some gaps in the Genesis 1-2 narrative with details. He describes God's actions when he created Eve out of Adam in terms of surgery. Chrysostom often calls God an expert

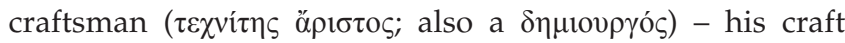
( $\tau \dot{\varepsilon} \chi \vee \eta$ or ars) is surgery. The practice of medicine and surgery was considered a $\tau \dot{\varepsilon} \chi v \eta$ in ancient Greek thought (Von Staden 1999:266-267; Walshe 2016:181). What makes God such an excellent surgeon is the fact that he can operate on the body without causing it pain or damage. This attribute of God is practically Asclepic. The Greek god of healing and medicine, Asclepius, was also famous for being able to conduct miraculously painless surgeries, mostly while the patient was asleep. Adam's sleep in Genesis during the generation of Eve shows remarkable similarities with the incubation

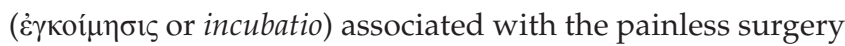
and healing of Asclepius (Rigato 2015:25-26).

Chrysostom basically pre-empts modern-day anaesthetics in this passage. He notes that the sleep that overcame Adam was not a normal sleep - this incubatio totally shielded him from all feeling and pain. Although one human being is being fashioned or 'born' from another, Chrysostom does not use the traditional language of childbirth to describe the generation of Eve. He prefers to use the language of surgery and craftsmanship. The painlessness of God's surgery attests to the effectiveness and wonder of the divine anaesthetic. Pain during surgery was a major problem for ancient patients because of the absence of proper anaesthetic (Le Blay 2016:371-385; Samellas 2015:287-289). Pain, in ancient thought, was mostly related to divine punishment (King 1998:123-124) as is also evident from Genesis 3:16 (see Cobb 2017, for the complexity of Christian responses to the problem of pain).

Furthermore, the problem of postlapsarian reproduction is that, due to sexual intercourse, the body does not remain whole - there is a loss of virginity, which is very problematic to Chrysostom who considers virginity akin to the angelic prelapsarian state of Adam and Eve. Chrysostom sadly states: 
So, at the outset and from the beginning the practice of virginity was in force; but when through their indifference disobedience came on the scene and the ways of sin were opened, virginity took its leave for the reason that they had proved unworthy of such a degree of good things, and in its place the practice of intercourse took over for the future. (Hom. Gn. 18.12; Migne PG 53.153.9-15; Hill 1999a:10-11)

There is a pun here on the loss of virginity, when Adam and

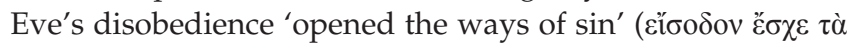
$\tau \tilde{\eta} \varsigma \dot{\alpha} \mu \alpha \rho \tau i \alpha \varsigma)$ - the loss of virginity is also the loss of the angelic body. The postlapsarian body now has a pain narrative, and pain receives a mnemonic function; it serves as a reminder of God's punishment for human disobedience:

'I will ensure', he [God] is saying, 'that the generation of children, a reason for satisfaction, for you will begin with a pain so that each time without fail you will personally have a reminder, through the distress and the pain of each birth, of the magnitude of this sin of disobedience.' (Hom. Gn. 17.31; Migne PG 53.143.52-57; Hill 1999a:238)

Yet, by the grace of God, Chrysostom also states that the maternal affection experienced in having children also serves as a consolation, showing that God is merciful even in his punishment (Hom. Gn. 17.32; Migne PG 53.144.6-18; Hill 1999a:238-229).

Chrysostom further believes that marriage, coitus and procreation caused old age and death to enter into the world (Hom. Gn. 17.40-42; Migne PG 53.146.27-147.40; Hill 1999a:243-245). 'For where death is, there is marriage. When one does not exist, the other is not about', Chrysostom explains, 'But virginity does not have this companion' (Virg. 14.6.70-72; Musurillo 1966:142-143; Shore 1983:22). Martin (2006:105) is also correct in saying: 'Marriage, therefore, was completely implicated in the dreaded cycle of sex, birth, death, and decay, followed by more sex, birth, death, and decay.' Early Christianity, from the time of Jesus and Paul as well as Chrysostom, positioned itself against the primacy of marriage, procreation and the household - these figures expected humanity to end so that the end times may begin (Martin 2006:103-124).

In Chrysostom's contrast between pre- and postlapsarian generation, we also observe that sterility ( $\dot{\alpha} \pi \alpha 1 \delta i ́ \alpha)$, plays an important role and unlike some common ancient understandings, sterility was in fact not a form of divine punishment or a disease (Niiranen 2016:223-240). Chrysostom exclaims:

They [Abraham, Isaac and Jacob] were in all respects bright and esteemed, but all of them had barren wives, and lived without children until an advanced age. Thus, when you see a husband and wife yoked together in virtue, when you see them favoured by God, giving heed to piety, but diseased with sterility, do not assume that the childlessness is in any way a retribution for sins. (Pecc. 6; Migne PG 51.359.25-31)

The sterile wives of Abraham, Isaac and Jacob, according to Chrysostom, function almost prophetically: they are types of the forthcoming virgin birth of Christ.
To summarise: in our analysis of how Chrysostom will interpret spiritual rebirth, it was necessary to start with his reading of the generation of Adam, Eve and their children in Genesis 1-2, because this gives us a firm understanding of how Chrysostom views birth more generally. In Van der Watt's terms (2000:139-140), this provides us with the context and socio-historical ecology of Chrysostom's exposition of the metaphor of spiritual birth. Chrysostom thus notes a shift from an ideal mode of reproduction, which is prelapsarian, to a deviant postlapsarian mode of reproduction. There were three important differences in this regard: first, the prelapsarian generative body was perfect and angelic, which is also virginal. Second, prelapsarian ideal reproduction was not based on the stirring of the passions. Finally, prelapsarian reproduction and birth was painless and left the body intact and virginal against the opposite of postlapsarian reproduction and birth, which always implied the painful rupture of the body during sex and labour. It is important to mark this event in Chrysostom's thought, because he will base his exposition of spiritual birth and rebirth, as we will see, on the principles he deduces from Genesis 1-2.

\section{Birth as a symbol in the history of salvation: The cases of Sarah and Mary}

Now that we have determined how Chrysostom understands pre- and postlapsarian modes of reproduction and birth, it is possible to analyse his understanding of Christian sexual morality in these terms. In other words, it becomes possible to identify which practices constitute a move towards or away from ideal prelapsarian modes of generation. For the purpose of this article, we will specifically look at reproductive and birth events that signify a move towards the ideal prelapsarian state. Within the complex development of early Christian soteriologies (see Van der Watt 2005b:505-522), birth was a very common and important soteriological discourse in early Christian literature (Solevåg 2013; Stovell 2016:27-44).

Chrysostom marks the birth of Isaac by Sarah (Gn 21:1-8) and, to a lesser extent, the birth of Joseph by Rachel (Gn 30:22-24) - both mothers being infertile, with their husbands Abraham and Jacob impregnating the slave girls Hagar and Bilhah respectively - as some of the major typological events in Christian soteriology. He describes Sarah, for instance, in terms related to prelapsarian human generation. First is the notion that Sarah was not stirred by the passions. 'Do you see how independent they [Sarah and Rachel] were of any emotional influence?' Chrysostom (Hom. Gn. 38.4; Migne PG 53.352.1; Hill 1999b:357) enquires. He also does not hesitate to highlight Sarah's 'philosophical mind-set' ( $\gamma \nu \omega ́ \mu \eta v)$ and 'the extraordinary degree of her self-control' ( $\tau \tilde{\eta} \varsigma$

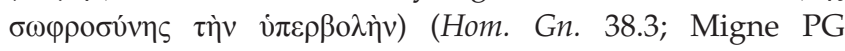
53.351.45-46; Hill 1999b:356). Just as Abraham's sexual encounter with Hagar was passionless (Hom. Gn. 38.1-2; Migne PG 53.351-353; Hill 1999b:355-356; Hom. Eph. 20.6; Field 1849-1862, 4.313-314), so is Sarah's mind-set also 
without passion - both Abraham and Sarah show remarkable self-control, similar to that of the angels.

Furthermore, despite of the fact that Sarah does conceive via sexual intercourse with Abraham, the conception of Isaac is still, to Chrysostom, miraculous. It affirms the point that procreation can only occur by God's approval. Chrysostom confirms that some men attribute:

sterility and fecundity to their wives without acknowledging that everything comes from nature's Creator and that neither intercourse nor anything else is capable of ensuring succession unless the hand from above intervenes and prompts nature to birth. (Hom. Gn. 38.4; Migne PG 53.352.13-18; Hill 1999b:358)

But the conception of Isaac by Sarah, in Chrysostom's thought, also serves to prepare the believer for the miraculous virgin conception and birth of Jesus. Chrysostom explains:

There were then two impediments [for Sarah], both the untimeliness of her age and the obsoleteness of nature, but in the case of the Virgin there was only one hindrance, namely not having participated in marriage. The barren one therefore prepares the way for the virgin. (Pecc. 7; Migne PG 51.359.51-54)

Being physically sterile and unmarried are actually all attributes of the prelapsarian generative condition. This is also why the fact that Mary conceives and gives birth premaritally is not a problem for Chrysostom - Jesus' birth and Mary's sexuality, overall, are not subject to postlapsarian reproductivity or even postlapsarian norms of sexual morality. Chrysostom actually goes to great lengths to distance Mary from the institution of marriage. Like Adam and Eve before the Fall, Mary, too, was a virgin - her body was still intact. We see again a climactic development in Chrysostom's soteriological thought: what makes Mary superior to Sarah is that Mary was still a virgin and not married, which also counts against Sarah. Chrysostom explains:

Do not seek the sequence of nature, Gabriel says to Mary, when that which is transpiring is above nature; do not look around for marriage and pangs of childbirth, when the manner of the birth is greater than marriage. 'And how will this be,' she says, 'since I do not know a husband' [Lk 1:34]. But exactly because of the fact that you know no husband, this will come to pass. For if you did know a husband, you would not have been deemed worthy to aid in this service. Thus, believe for the same reason that you disbelieve. And you would not have been deemed worthy to serve this duty, not because marriage is an evil, but because virginity is superior, and it was fitting that the entry of the Master should be more dignified than ours. For it was royal, and the king enters through one more august. It was also necessary that he should share in human birth, yet be different from ours. In this way both these aspects are managed. For being born from the womb is common among us, but the being born without marriage [i.e. sexual intercourse] is greater than what happens among us. And the gestation and conception in the womb belongs to human nature, but that the pregnancy should occur without sexual intercourse is too dignified for human nature. And for this purpose both these things happened, in order that you may learn both the superiority and the communal fellowship of him who was born. (Pecc. 7-8; Migne PG 51.360.6-28)
Mary's body should be understood as a type of transitional body in Chrysostomic thought. Her reproductive corporeality lies somewhere between the prelapsarian and postlapsarian generative states. She has all the characteristics of prelapsarian generation - her perfect virginal body and a passionless conception. Yet, in the Mariology of Chrysostom, Mary is neither perfect nor is she in a higher rank of holiness. Chrysostom says:

Now if, setting aside the eminence of her soul, it benefitted Mary nothing that the Christ was born of her, much less will it be able to profit us to have a father or a brother, or a child of virtuous and noble character, if we ourselves fall short of his virtue. (Hom. Jn. 44.3; Migne PG 59.132.1-6)

Chrysostom's is therefore a 'low' Mariology - he even blamed Mary for being vain and a troublemaker (Meyendorff 1979:148; Perry \& Kendall 2013:32, 56). Mary's transitional body therefore births him who is without sin and perfect, but her body, as such, is not yet fully perfect.

Furthermore, Chrysostom subscribed to the painless birth of Jesus and the perpetual virginity of Mary. In Pecc. 7, cited above, Chrysostom says that one should not look for 'the

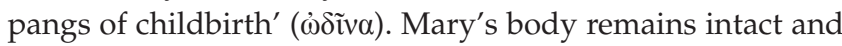
her virginity is not ruptured by sexual intercourse or regular human birth. As with Adam, she stays a virgin before and after the birth. Chrysostom's Mariology also exhibits a mystical character. For Chrysostom, the virgin birth and, more generally, Mary's sexuality is something that is mysterious. Like the nature of Christ and the Trinity, it cannot be understood in human terms. Chrysostom says that we do not know how the infinite is in a mother, how he that encapsulates everything is carried, not yet born, by a woman; how the virgin bears, and remains a virgin' (Hom. Mt. 4.3; Migne PG 57.43.15-17). Chrysostom also notes:

$[N]$ ot even after the birth, she having become a mother in such a way, and having been deemed worthy of a new kind of travail, and a parturition so strange, could that righteous man [i.e. Joseph] ever have endured to know her. For if he had known her, and had kept her in the place of a wife, how is it that our Lord commits her, as an unprotected woman, and having no one, to his disciple, and commands him to take her to his own home [Jn 19:27]? (Hom. Mt. 5.3; Migne PG 57.58.39-43)

Therefore, Joseph simply could not have sexual intercourse with Mary after the birth of Jesus. The fact that Jesus has brothers is equally mystical. Chrysostom calls all of these seeming inconsistencies 'veils' that hide the mystery of the virgin birth (Hom. Mt. 5.3; Migne PG 57.58.39-43). The human

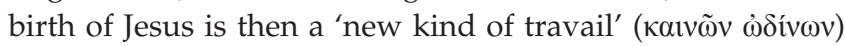

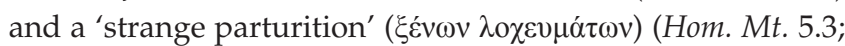
Migne PG 57.58.39-43). Just as Adam and Eve, and all humankind were sentenced to perpetual reproduction through sexual intercourse, now Mary's transitional body represents a major shift back to perpetual virginity and ideal prelapsarian generation.

Glancy (2010:115-117) argues, in her analysis of the Protevangelium Jacobi where Salome tempts God by probing 
Mary's post-partum virginity (see Prot. Jas. 20; Hock 1995:68-69), that Mary's body becomes untouchable, and the act of the virgin birth thereby signifies a return to a pure and unadulterated mode of reproduction (see also Lillis 2016:1-28). This point also seems to stand with regard to Joseph in Chrysostom's reading of the narrative of Jesus' birth. Unlike Salome, though, Joseph is absolutely aware of Mary's holy state and he does not dare to touch her ever again. As the birth of Eve was painless for Adam, so, too, was Christ's birth. As God replaced Adam's rib and mended his side, so too is Mary's virginity intact after the birth - her body remains unchanged and not violated in any sense. Mary and all the virgins of the church are thus freed from the curse of Eve and the punishment of postlapsarian reproduction. Jerome has a similar view in his treatise on the perpetual virginity of Mary. He explains:

She who is not subject to the anxiety and pain of childbearing and having been withdrawn from menstruation, has ceased to be a woman, is freed from the curse of God, nor is her attraction to her husband, but on the contrary, her husband becomes subject to her. (Adv. Helv. 22; Migne PL 23.214.38-42)

The virgin is no longer a 'slave' to her husband in marriage, but truly free, and even her 'husband', Joseph, becomes 'subject' to her, theoretically. But the virgin birth of Christ, as foreshadowed by the birth of Isaac, is not the final climax in Chrysostom's opera of salvation. This is the point where we turn to the notion of spiritual rebirth.

\section{The climax of salvation: Being born of the Spirit}

The image of generation and regeneration therefore develops climactically with regards to Christian salvation history. This use of metaphorical and typological progression was a common pedagogical strategy in Chrysostom (Rylaarsdam 2014:91, footnote 239; Brown 1988:350-352). There is the move from prelapsarian to postlapsarian generation and then a slow return, starting with the miraculous conception of barren Old Testament women like Sarah, and most importantly, the virgin birth of Jesus. It is, however, in spiritual birth that we find the climax of generative salvation in Chrysostom's thought. The birth of Christ also points to the rebirth of all believers:

Because He begets without passion, for this reason did she that was barren first bear. But there is an even higher meaning - it was necessary to be believed that he begot of himself. What then? This happens, but obscurely, as in a type and a shadow, but it still does happen, and as it progresses it becomes somehow clearer. A woman is formed solely out of man, and he remains whole. Again, it was necessary there should be some proof of the conception of a virgin. So the barren bears, not only once, but a second and a third time, and many times. The barren is then a type of his birth from a virgin, and she sends the mind forward to faith. Again, this was a type of God being able to beget alone. For if man is the active agent, and birth takes place without him, much more is the one who is begotten from the divine active Agent. And there is another generation, which is a type of the truth - that is, ours which is from Spirit. The barren one is of this, again, a type, that it is a birth not from blood [ $n n$ 1:13]. This refers to being born from above [ $J n$ 3:3]. On the one hand, it shows that the generation is without passion; on the other, that it could be generated from one alone. This one is Christ above, ruling over all things: it was necessary that this should be believed. (Hom. Col. 5.4; Field 1849-1862, 5.230-231)

Chrysostom rounds off this passage chiastically with the repetition of $\varepsilon \delta \varepsilon 1 \pi \imath \tau \varepsilon \varepsilon v \theta \tilde{\eta} v \alpha l$, showing the importance of faith in the event of spiritual birth. The birth events of Sarah and Mary were given in order to school the believer in faith. The great mystery, which is pointed out by Chrysostom, is in that God actually begot himself. He also states above that Christ was born from, and not through, a virgin, similar to what was said earlier about Adam in Hom. 1 Cor. 26.5 (Field 1849-1862, 2.317-318). It is a mystery that would not be easily grasped. God thus revealed it slowly and progressively through all these Old Testament types. The last progression towards prelapsarian reproduction, before the eschaton, is the rebirth of Christians from the Holy Spirit

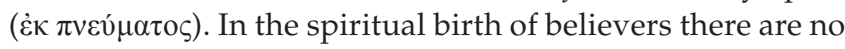
birth pains, no passion, and it springs from Christ, the second Adam. This birth is then yet another progression towards ideal generation. At the same time, human birth is devalorised:

For Isaac, born not according to the order of nature, nor the law of marriage, nor the power of the flesh, was still Abraham's own son. He was the son of bodies that were dead, and of a maternal womb that was dead. His conception was not by the flesh, nor his birth by the seed, for the womb was dead both through age and barrenness, but the word of God fashioned him. Unlike the case of the slave. He came by the ordinances of nature, and was conceived by the intercourse following marriage. Nevertheless, he who was born not according to the flesh was more honourable than he who was born according to the flesh. Now then, let it not upset you if you are not born after the flesh. For because you are not born in this manner, are you most of all Abraham's generation. Being born according to the flesh does not render one more honourable, but less so. For a birth not according to the flesh is more wondrous and more spiritual. And this is clear from those who were born from above. For Ishmael, who was born according to the flesh, was not only a slave, but was cast out of his father's house. But Isaac, who was born according to the promise, being a true son and free, was a master of all. (Comm. Gl. 4.23; Field 1849-1862, 4.73)

Chrysostom here uses the image of slavery to inform his discourse of spiritual regeneration. Human birth, that is, the birth through the flesh, enslaves the individual in similar terms to Ishmael, but because Isaac had a miraculous spiritual birth, he is truly free. Spiritual rebirth is freedom from the slavery of the sinful flesh (Hom. Jn. 26.1; Migne PG 59.153.5154.58; see also Naidu 2012:83-167). Chrysostom explains while interpreting John 3:6:

There is no longer a mother, or birth pains, or sleep, and intercourse and embraces of bodies. From this point on, all the fabric of our nature is woven above, of the Holy Spirit and water. The water is employed, being made the birth to the one who is born. What the womb is to the embryo, the water is to the believer; for in the water the believer is fashioned and formed. (Hom. Jn. 26.1; Migne PG 59.153.25-32) 
The baptismal font is the symbol of the new spiritual womb, the baptismal water the new amniotic fluid of spiritual birth. In spiritual rebirth there is a shift back to all the characteristics of ideal prelapsarian generation - there is no pain, no passion, and spiritual rebirth is the first step towards regaining the perfect angelic body, that is, the resurrected body. It also implies a new kinship and a new identity (Van der Watt 2000:161-200).

\section{Conclusion}

Chrysostom's view of spiritual rebirth cannot be understood outside of his broader interpretative framework, which starts with the generation of Adam and Eve, takes account of the Fall and the beginnings of sexual reproduction, and recoups itself with the miraculous births of Isaac and Jesus. In this sense, the believer becomes encapsulated in God's salvation history. Van der Watt (2000:177) refers to this as the metaphorical network, which is quite expansive in the case of Chrysostom (as compared, for instance, to the birth metaphor in the Gospel of John). The believer becomes part of the family of God. There is a similar development of the metaphorical imagery of birth and family in Chrysostom in Van der Watt's reading (2000:400-406) of the metaphor in its Johannine context. Van der Watt (2000) makes a very important point:

Since John develops the family imagery in a complex way, an integrated figurative world is created, which metaphorizes aspects of the earthly world - an analogy is drawn between two different realities, namely earthly and heavenly realities. (p. 401)

Chrysostom's metaphorical construction is similar - it is both vertical and horizontal. Vertically, there is the analogy between heavenly (spiritual) and earthly generation, and horizontally, there is the progressive development of birth from the sinful fleshly birth to ideal spiritual regeneration.

\section{Acknowledgements}

This article hereby acknowledges the work, impact, and general support of Prof. Jan van der Watt on the author's own academic development and career. It is therefore also dedicated to Prof. Van der Watt.

\section{Competing Interests}

The author declares that he has no financial or personal relationships which may have inappropriately influenced him in writing this article.

\section{References}

Blowers, P.M., 2012, Drama of the divine economy: Creator and creation in early Christian theology and piety, Oxford University Press, Oxford.

Brottier, L. (ed.), 1998, Jean Chrysostome: Sermons sur la Genèse, Éditions du Cerf Paris.

Brown, P.R.L., 1988, The body and society: Men, women, and sexual renunciation in early Christianity, Columbia University Press, New York.

Clark, E.A., 1979, Jerome, Chrysostom, and friends: Essays and translations, Edwin Mellen, Lewiston.
Clark, G., 2015, 'Deficient causes: Augustine on creation and angels', in A. Marmodoro \& B.D. Prince (eds.), Causation and creation in late antiquity, pp. 220-236, Cambridge University Press, Cambridge.

Cobb, L.S., 2017, Divine deliverance: Pain and painlessness in early Christian martyr texts, University of California Press, Oakland.

De Beer, W., 2015, 'The patristic understanding of the six days (Hexaemeron)', Journa of Early Christian History 5(2), 3-23.

De Wet, C.L., 2015, Preaching bondage: John Chrysostom and the discourse of slavery in early Christianity, University of California Press, Oakland.

Dumortier, J. (ed.), 1955, Saint Jean Chrysostome: Les cohabitations suspectes; Comment observer la virginité, Les Belles Lettres, Paris.

Field, F. (ed.), 1849-1862, Sancti patris nostri Joannis Chrysostomi archiepiscopo Constantinopolitani interpretatio omnium epistularum Paulinarum homilias facta, 7 vols., J.H. Parker, Oxford.

Gaca, K.L., 2003, The making of fornication: Eros, ethics, and political reform in Greek philosophy and early Christianity, University of California Press, Berkeley.

Glancy, J.A., 2010, Corporal knowledge: Early Christian bodies, Oxford University Press, Oxford.

Hill, R. (ed. \& transl.), 1999a, St. John Chrysostom: Homilies on Genesis 1-17, Catholic University of America Press, Washington, DC.

Hill, R. (ed. \& transI.), 1999b, St. John Chrysostom: Homilies on Genesis 18-45, Catholic University of America Press, Washington, DC.

Hock, R.F., 1995, The infancy gospels of James and Thomas, Polebridge, Santa Rosa.

King, H., 1998, Hippocrates' woman: Reading the female body in ancient Greece, Routledge, London.

Lampe, G.W.H., 2010, A patristic Greek lexicon, Oxford University Press, Oxford.

Le Blay, F., 2016, 'Surgery', in G.L. Irby (ed.), A companion to science, technology, and medicine in ancient Greece and Rome, pp. 371-385, Wiley, Malden.

Lillis, J.K., 2016, 'Paradox in partu: Verifying virginity in the Protevangelium of James', Journal of Early Christian Studies 24(1), 1-28.

Malingrey, A-M. (ed.), 1980, Jean Chrysostome: Sur le sacerdoce, Éditions du Cerf, Paris.

Martin, D.B., 2006, Sex and the single savior: Gender and sexuality in biblical interpretation, Westminster John Knox, Louisville.

McDonough, S.M., 2009, Christ as creator: Origins of a New Testament doctrine, Oxford University Press, Oxford.

Meyendorff, J., 1979, Byzantine theology: Historical trends and doctrinal themes, Fordham University Press, New York.

Migne, J-P. (ed.), 1844-1864, Patrologiae cursus completus: Series ecclesiae latinae, 217 vols., Imprimerie Catholique, Paris.

Migne, J-P. (ed.), 1857-1886, Patrologiae cursus completus: Series Graeca, 162 vols. Imprimerie Catholique, Paris.

Mitchell, M.M., 2002, The heavenly trumpet: John Chrysostom and the art of Pauline interpretation, Westminster John Knox, Louisville.

Muehlberger, E., 2013, Angels in late ancient Christianity, Oxford University Press, New York.

Musurillo, H. (ed.), 1966, Jean Chrysostome: La virginité, Éditions du Cerf, Paris.

Naidu, A.J., 2012, Transformed in Christ: Christology and the Christian life in John Chrysostom, Pickwick, Eugene.

Niiranen, S., 2016, 'Sexual incapacity in medieval Materia medica', in C. Krötzl, K. Mustakallio \& J. Kuuliala (eds.), Infirmity in antiquity and the Middle Ages: Social and cultural approaches to health, weakness and care, pp. 223-240, Routledge, Abingdon.

Perry, T. \& Kendall, D., 2013, The blessed virgin Mary, Eerdmans, Grand Rapids.

Piédagnel, A. (ed.), 1966, Jean Chrysostome: Panégyriques de S. Paul, Éditions du Cerf, Paris.

Rigato, D., 2015, 'Medicines, doctors, and patients in Greek and Roman society', in M. Malatesta (ed.), Doctors and patients: History, representation, communication from antiquity to the present, pp. 23-51, University of California Medical Humanities Press, San Francisco.

Rylaarsdam, D., 2014, John Chrysostom on divine pedagogy: The coherence of his theology and preaching, Oxford University Press, New York.

Samellas, A., 2015, 'Public aspects of pain in late antiquity: The testimony of Chrysostom and the Cappadocians in their Graeco-Roman context, Zeitschrift für antikes Christentum 19(2), 260-296.

Shaw, B.D., 1996, 'Seasons of death: Aspects of mortality in Imperial Rome', Journal of Roman Studies 86, 100-138.

Shepardson, C., 2014, Controlling contested places: Late antique Antioch and the spatial politics of religious controversy, University of California Press, Berkeley.

Shore, S. (ed. \& transl.), 1983, John Chrysostom: On virginity; Against remarriage, Edwin Mellen, Lewiston.

Solevåg, A.R., 2013, Birthing salvation: Gender and class in early Christian childbearing discourse, Brill, Leiden.

Stovell, B.M., 2016, 'The birthing Spirit, the childbearing God: Metaphors of motherhood and their place in Christian discipleship', in B.M. Stovell (ed.), Making sense of motherhood: Biblical and theological perspectives, pp. 27-44, Wipf \& Stock, Eugene,

Van der Watt, J.G., 2000, Family of the king: Dynamics of metaphor in the Gospel according to John, Brill, Leiden. 
Van der Watt, J.G., 2005a, 'Salvation in the Gospel according to John', in J.G. van der Watt (ed.), Salvation in the New Testament: Perspectives on soteriology, pp. 101132, Brill, Leiden.

Van der Watt, J.G., 2005b, 'Soteriology of the New Testament: Some tentative remarks', in J.G. van der Watt (ed.), Salvation in the New Testament: Perspectives on soteriology, pp. 505-522, Brill, Leiden.

Van der Watt, J.G., 2006, Radical social redefinition and radical love: Ethics and ethos in the Gospel according to John', in J.G. van der Watt (ed.), Identity, ethics, and ethos in the New Testament, pp. 107-134, De Gruyter, Berlin.
Van der Watt, J.G., 2013, 'Reflections on doing what is good and true in the Gospel of John', in F.W. Horn, U. Volp \& R. Zimmermann (eds.), Ethische Normen des frühen Christentums, pp. 73-92, Mohr Siebeck, Tübingen.

Von Staden, H., 1999, 'Celsus as historian?', in P.J. van der Eijk (ed.), Ancient histories of medicine: Essays in medical doxography and historiography in classical antiquity, pp. 251-294, Brill, Leiden.

Walshe, T.M., 2016, Neurological concepts in ancient Greek medicine, Oxford University Press, New York. 